\title{
Taking Portfolios Difference Seriously: A Composite Measure Based on Policy, Office, and Budget in Brazil*
}

\author{
Mariana Batista \\ Universidade Federal de Pernambuco, Brazil
}

\begin{abstract}
Portfolio allocation is the keystone of coalition government analysis. It constitutes the fundamental payoff in coalition formation, providing access to government decision-making. However, are all portfolios the same or have the same weight in government decisionmaking? This research note presents a measure of portfolio differences based on three dimensions: policy, office, and budget. Factor analysis is used to generate a composite indicator of portfolio importance in Brazil from 1999 to 2014. Results show that portfolios vary significantly in importance in each of the three dimensions, meaning that a ministry of little importance in one dimension can be very important in another. With policy, office, and budget combined, the most important ministry is the Ministry of Finance and the least important is the Ministry of Fishery. This indicator is the first step to summarize the differences between ministries that can be used to inform empirical analysis about coalition formation and governance in Brazil.
\end{abstract}

Keywords: Coalition governments; portfolio differences; policy; office; budget.

(*) http://dx.doi.org/10.1590/1981-3821201700010006

For data replication, see bpsr.org.br/files/archives/Dataset_Batista

I kindly acknowledge the valuable comments received from Octávio Amorim Neto and BPSR's anonymous reviewers. 
t has become common to say that portfolios are not all the same. The Health Ministry is not the same as the Sports Ministry, the Integration Ministry is not as important as the Finance Ministry. However, comprehensive classifications are somewhat difficult to assemble and subject to criticism due to the complexity of the issue. For this reason, experts' common practice has been to abstract the differences and analyze portfolios as equivalent, even though most of us agree that they are not (AMORIM NETO, 2000).

However, in what ways do these ministries differ? How can we measure and analyze these differences systematically? Is there a way to identify the relative 'importance' of portfolios? 'Who gets what' in portfolio allocation is a prevalent question in the coalition formation debate in multiparty parliamentary systems. However, the precise distribution of portfolios has not always been a relevant subject.

In the classic approach to coalition formation, what matters is the number or proportion of portfolios each coalition party receives in government. Often referred to as Gamson's Law and associated with office-seeking approaches to government formation, the proportionality principle follows from the perspective of government as a prize, and portfolios as sub-units to be shared among coalition partners according to the number of legislative seats contributed to the coalition (BUDGE and LAVER, 1986; GAMSON, 1961). What matters is the party's share of the prize, regardless of the precise distribution of portfolios (BUDGE and LAVER, 1986). For this reason, portfolios are treated as equivalents in empirical applications.

In more recent analyses of coalition formation and coalition governance, office is not valued for itself, but as an instrument to achieve policy goals or votes in the next election. For this reason, portfolios are valued differently according to their policy salience. In this perspective, the precise distribution of portfolios is of central concern. Some ministries are more salient than others, and some ministries are more salient to specific parties than others. The main empirical implication of the salience argument is that the 'prize' is not composed of equivalent or homogenous parts and this fact must be taken into consideration in the proportionality calculus (LAVER and HUNT, 1992; WARWICK and DRUCKMAN, 2001). 
Portfolio equivalence is still the most common way to analyze portfolio allocation, especially because of its simplicity and comparability across cases. However, despite these gains, the case for important differences between ministries still remains. Saliency theory presents a way to include portfolio heterogeneity in the analysis. However, this option is only effective when political parties are perceived as programmatic or policy-oriented.

The measure presented in this research note is between these two perspectives. We presuppose that portfolios are not all the same. However, policy salience is not the only way to consider these differences ${ }^{1}$. Our approach is based on different office perks valued by coalition partners when deciding to join government. These perks may be considered assets that the party will control once in government and that can be used as an office perk in itself, as a way to influence policy or to reach their constituency directly. These assets are identified as dimensions that differentiate the ministries: office, policy, and budget. Considering these three dimensions simultaneously, we propose a measure of portfolio importance that can be used to adjust proportionality measures and also to better understand coalition formation and governance.

To propose and evaluate this measure we analyze the Brazilian case. Brazil is a multiparty presidential system with a long tradition of coalition governments. These coalitions seem to be effective in generating stability and legislative support for the president's agenda (FIGUEIREDO and LIMONGI, 2001). However, parties present weak programmatic linkages (MAINWARING, 2001), and legislative behavior is often related not only to ideological proximity but also to pork-barrel politics (PEREIRA and MUELLER, 2003).

We assume that coalition partners value office instrumentally, and that what parties want in government is related to policy, office, and budget. To calculate the indicator we use data from Brazil during the 1999 to 2014 period. The rest of this research note is organized as follows: In the next section, we present the office-seeking versus policy-seeking debate that underlies the different measures, and present our perspective. In the third section, we present the data and methods. In the fourth section, we present the results. Finally, the conclusion.

\footnotetext{
1 This does not mean that policy salience is not a relevant issue in less programmatic contexts. However, it is not the approach followed here.
}

(2017) $11(1) \quad$ - 


\section{Sharing the prize: office-seeking and policy-seeking approaches}

Government formation is one of the most important topics in positive political science. It is about the translation of electoral results in executive power. In presidential systems, where there is a clear separation of origin and survival, presidents are elected independently from the parliament, so whoever gets the majority of votes becomes the head of the executive. In parliamentary systems the executive is dependent on parliament. When a single party holds the majority of seats, government formation is also straightforward. Explanations become more complex when a coalition is necessary to government formation, becoming a bargain about who gets what.

"Power is the currency of politics" (GAMSON, 1961, p. 374). Based on this assertion, Gamson (1961) proposed the proportionality principle, or Gamson's Law, as the rule on portfolio allocation, solving the problem of who gets what in coalition formation. Gamson (1961) defines a coalition as the joint use of resources to achieve an outcome. To reach the outcome, a critical amount of resources is necessary, and there is a payoff to each participant as a reward for their contribution in terms of resources. In the case of coalition formation, participants are political parties, the outcome is government formation, resources are legislative seats, and the payoff is a share of government in terms of portfolios. According to Gamson (1961), the rule organizing portfolio allocation is the proportionality rule: "Any participant will expect others to demand from a coalition a share of the payoff proportional to the amount of resources which each contribute to a coalition" (GAMSON, 1961, p. 376).

After countless empirical applications using the proportion of legislative seats as a measure of resources and the proportion of portfolios as a measure of payoff, Gamson's Law has become "one of the highest nontrivial r-squared figures in political science (0.93)" (LAVER, 1998, p. 04).

Underlying this proportionality principle in portfolio allocation is the officeseeking approach to political parties. The office-seeking approach argues that what parties want is to become more influential in government, maximizing their share in government decision-making power, translated in the number of ministries the parties control. "Simply to get into the executive, almost regardless of the precise distribution of portfolios, is probably the most salient payoff" (BUDGE and LAVER, 1986, p. 491).

Later developments of the model included ideology to predict coalition formation. To these arguments, some coalitions are more likely to form than others 
based on ideological proximity between coalition partners (AXELROD, 1970; SWAAN, 1973). The general argument is that ideologically compact coalitions are more valued because they are less costly in terms of policy compromise. For this reason, including ideology in the coalition formation argument means that office is not valued in itself, but as an instrument to implement the party's policy preferences.

The policy-seeking approach argues that political parties are policy-oriented and that cabinet seats are considered instruments to implement the party's policy agenda. Important to this perspective is the analysis of the executive branch as a decision-making arena. According to Laver and Shepsle (1996), in the office-seeking approach, "cabinet portfolios, once allocated, are simply consumed as benefits by the legislative parties that hold them" (LAVER and SHEPSLE, 1996, p. 12). However, governments implement policy decisions; it is not a set of perks to be consumed for itself at the end of the coalition bargain.

The concern with what happens after coalition formation has informed the debate about policy preferences in portfolio allocation. For these models the question of who gets what becomes much more complex, and the real challenge is to predict the precise distribution of portfolios and not just the share. Different parties have different preferences on specific ministries, and this is fully connected to the fact that once in government they will control policymaking in those specific issue areas (LAVER and SHEPSLE, 1990). The prime minister's position is fundamental to all parties. However, for a party linked to industrial interest groups the Ministry of Industry appeals directly to their constituency; for an agrarian party it is of great interest to control the Ministry of Agriculture; and for a green party the Ministry of Environment may be more important than others (LAVER and HUNT, 1992; WARWICK and DRUCKMAN, 2001).

These differences are fundamental to saliency theory. Each party has a policy position and different parties value different issues differently. The debate's main contribution to coalition formation analyses is that the 'prize' is not composed of homogeneous sub-units, and this fact should be considered in proportionality calculations.

From an empirical point of view, Laver and Hunt (1992) present the main contribution, bringing together the results of a survey designed to identify the relative salience of each ministry. Warwick and Druckman (2001) enhanced the measure, presenting a continuous measure of ministerial salience, taking into account not only the 
ordinal difference between ministries, but also by calculating how much each ministry is more important than the others. More recently, some measures have been developed using not only survey data but also parties' manifestos as source of policy emphasis (LAVER, 2001).

Laver and Schofield (1990) propose an integrated approach emphasizing that players in coalition games have mainly two motivations: the desire to gain office and the desire to influence policy. For this reason, the payoffs should be measured in terms of office perks and policy influence:

We must evaluate the distribution of coalition payoffs in the same basic currencies that we consider to motivate the actors. This means that we must look at both the office and the policy payoffs of coalition bargaining and consider both the intrinsic and the instrumental reasons for wanting these payoffs (LAVER and SCHOFIELD, 1990, p. 165).

As office payoffs, the authors discuss the distribution of patronage, such as jobs in the administration to political supporters outside the legislature, and also the proportion of the budget and the nature of the spending, beyond the numerical distribution of cabinet portfolios. Policy payoffs are related to the distance between party and government policy; the bigger the distance, the worse for the party. However, this negative impact is different according to the party's motivation. If the party is policy-seeking, this distance is important no matter what, but for office-seeking parties this distance is only important if the party is a member of the governing coalition and can be held electorally accountable for its decisions (LAVER and SCHOFIELD, 1990).

The office-seeking versus policy-seeking debate has its focus mainly in multiparty parliamentary systems, especially because of the widespread idea that presidential systems and coalition governments are incompatible (MAINWARING, 1993). However, comparing different political systems, Cheibub, Prezworswi, and Saiegh (2004) found that fragmented multiparty systems generate incentives for coalition governments in both parliamentary and presidential systems. This finding created an avenue for a whole new research agenda. It became urgent to understand when and how presidents form coalition governments and also what coalition partners want in government.

Amorim Neto (2006) provided the main contribution to the study of coalition governments in presidential systems. According to Amorim Neto (2006), presidential 
systems are not all the same. In fact, at the beginning of the mandate, the president chooses the government structure based on the legislative strategy. This choice relates to the status of government as majority or minority, the degree of partisanship of the cabinet, and the coalescence rate or the proportionality of legislative seats to portfolio share.

The coalescence rate soon became the main indicator in analyses about executive-legislative relations in presidential systems. Following the classic approach presented in Gamson's Law, the coalescence rate is based on the equivalence between different ministries. Amorim Neto (2000) presents the measure and explains the choice of the equivalence between ministries in the following passage:

One must notice that it [the measure] presumes that all portfolios are of the same value. However, in the real world of politics things are not like this: some ministries are more important than others. The Finance Ministry is a good example. However, any method used to quantify the different political values of portfolios will always be of low reliability and subject to criticism. For example, if we used the ministry's budget to measure the political value of each portfolio, a very valued job as the minister of Foreign Affairs would get a very low value in Brazil, in particular, and in Latin America, in general. Therefore, while recognizing that the assumption of the same political value for all ministries is an imperfect solution, I argue that it is more reliable than any attempt to quantify this value (AMORIM NETO, 2000, p. 483). (translated from Portuguese by the author)

Amorim Neto (2000) makes a very good point and we agree that measures trying to capture differences in value between ministries will be subject to criticism. However, we argue that this is an important debate that has to be considered. The main objective of this research note is to propose a way to consider these differences, minimizing the subjectivity of any measure based on a single dimension as Amorim Neto (2000) has pointed out above.

The first option would be to calculate differences in salience as the literature on parliamentary system has emphasized. However, this is a limited option when parties are not considered as programmatic as in western parliamentary systems. Experts' assessments on Brazilian party systems rarely describe it as programmatic, except for a few parties (MAINWARING, 2001). Extreme fragmentation and weak linkages in society are associated with the open list proportional representation system that reduces the role of political parties during elections (MAINWARING, 2001; NICOLAU, 2006). However, despite the parties' weakness in the electoral arena, parties have shown to be 
disciplined in the legislative arena, revealing an important leadership role in congress (FIGUEIREDO and LIMONGI, 2001). For this reason, a policy-seeking approach is not appropriate by itself, but it cannot be dismissed as a relevant dimension in the parties' calculus.

Another option is to consider the budget allocated to the ministry as a valued aspect of executive politics. Amorim Neto (2000) mentions this possibility and Laver and Schofield (1990) discuss this option as a form of 'office payoff'. As noted above by Amorim Neto (2000), Laver and Schofield (1990) also express concerns about using budget as a main indicator of portfolio importance because "the non-spending offices of Prime Minister, Foreign Affairs, and Finance are significantly more important than any other" (LAVER and SCHOFIELD, 1990, pp. 169-170). For this reason, budget too is not in itself a valid measure of importance, but should be taken into account, especially in the Brazilian political system where distributive politics are so often emphasized (PEREIRA and MUELLER, 2003).

Of course there is a third option that is the 'office for more office' argument. In this approach, parties want cabinet positions as a way to control valued patronage resources. Political parties in control of ministries use their power to control political appointments and reward political supporters. Despite the large appeal of this argument in the Brazilian political system due to the public administration's size, focusing on political appointments as the only valued asset in executive politics would be extremely narrow and somewhat mistaken since a large portion of political nominees are also public servants (PRAÇA, FREITAS, and HOEPERS, 2011).

Considering that influence over policy, budget allocation, and office distribution are all important to some extent, but are all limited if taken individually, one option is to take all three dimensions together to present a less limited measure of portfolio importance. Our approach to the problem is to consider these three dimensions as assets available to the party in control of the ministry. It does not mean that the party will control every policy decision, allocate the entire budget to its constituency, or use all political nominations as patronage. However, together these three dimensions may provide an indication of the relative importance of ministries to political actors. The next sections present the data, methods, and results. 


\section{Measuring portfolios' differences in Brazil}

In this section we present the data and methods used to build this new measure of portfolio importance. We use data from Brazil during the 1995 to 2014 period. Due to data availability we restrict the final indicator to the 1999 to 2014 period. All measures are presented by year in this period.

Brazil is an important case study because of its political system, a multiparty presidential system with coalition governments. Because parties are generally considered to be non-programmatic, we need a much broader definition of portfolio importance. To deal with this complexity we propose a definition that includes both office and policy payoffs, with three specific dimensions ${ }^{2}$ : policy, office, and budget. To operationalize these dimensions we use data from several different sources, combined into an original dataset.

The first dimension, 'policy', is observed as ministry participation in the executive's legislative agenda formulation. Policy is the number of legislative initiatives authored by the ministry ' $m$ ' in the year ' $t$ '. The analysis is based on each bill's authorship to identify the participation of each minister in the executive's legislative activity (BATISTA, 2013). Therefore, we identified the authorship of all legislative acts based on an internal document to the executive that is attached to every normative act called 'exposição de motivos' (explanatory statement). Based on this document it is possible to identify the ministers that formulated the legislative act. These documents were collected from the Civil House (Casa Civil/Chief of Staff) ${ }^{3}$ and from the Chamber of Deputies $^{4}$ systems. The dataset includes all ordinary laws (PL), constitutional amendments (PEC), provisional measures (MP), and complementary laws (PLP), a total of 1,784 legislative initiatives: 904 PLs, 56 PECs, 765 MPs, and 59 PLPs in the 1995 to 2014 period. This total considers all legislative initiatives submitted by the executive to congress, including bills approved, rejected, or still under consideration. No bills requesting extra credit were included in the analysis.

The second dimension, 'office', is identified as the number of political appointees located in the ministry ' $m$ ' in the year ' $\mathrm{t}$ '. The data's original source is the

\footnotetext{
2 The term 'dimensions' is used here as 'aspects' and not in the correlational sense used in the factor analysis.

${ }^{3}$ See http://www2.planalto.gov.br/acervo/legislacao. Accessed on February 12, 2016.

${ }^{4}$ See http://www2.camara.leg.br/. Accessed on February 12, 2016.
} 
Ministry of Planning5. Political appointments are known in Brazil as DAS, an acronym for 'Direção e Assessoramento Superior', or High Level Execution and Advisory (PRAÇA, FREITAS, and HOEPERS, 2011). Praça, Freitas, and Hoepers (2011) estimated that in 2010 there were 21,681 of these employees distributed across all ministries in the federal government. These DAS are ranked from 01 to 06 . DASs 01 to 03 are low-level positions with low salaries, and 04 to 06 are high-level positions in terms of responsibilities, skills (technical and political skills), and salaries (PRAÇA, FREITAS, and HOEPERS, 2011). Having a large number of these jobs available in the ministry does not mean that all positions will be used as patronage. Actually, civil servants, not political allies from outside the administration, occupy most of these positions, especially the high-ranked ones (PRAÇA, FREITAS, and HOEPERS, 2011). However, the distribution of political appointees, and the proportion of patronage, varies a lot between ministries and can be considered as an important asset to political parties at the top of the hierarchy.

The third dimension, 'budget', is the total budget available to the ministry ' $m$ ' in the year ' $t$ '. We also include in the analysis a separate variable with the investments budget that usually means the most 'flexible' part of the budget that can be politically allocated. Data comes from the Integrated System of Finance Administration (Sistema Integrado de Administração Financeira, SIAFI), available from the House of Deputies website $^{6}$. Again, we do not argue that the minister implements this budget freely. However, it constitutes an important asset, and surely the amount the ministry controls is one of the variables in the coalition partner's equation.

To achieve our objective of combining all three dimensions into a single indicator, we implement two strategies. First we present simple indexes, based on the sum of the values for our three variables. In this first approach, we present separately the index using the total budget and another using the investments budget, to compare the ministries' importance. Note that in this first approach all three variables have the same weight in the final indicator. To deal with this limitation, the second strategy is to use factor analysis. Factor analysis provides "the best linear combination of variables -

5 Through a request using the access to information law (Lei de Acesso à Informação, no $12.527 / 2011)$.

6 http://www2.camara.leg.br/atividade-legislativa/orcamentobrasil/orcamentouniao/loa/loa2016. Accessed on February 12, 2016. 
best in the sense that the particular combination of original variables accounts for more of the variance in the data as a whole than any other linear combination of variables" (HAIR JR. et al., 2009, p. 93). This technique is appropriate because it provides the tools for analyzing the structure of correlations among a set of variables, and identifying groups of interrelated variables that collectively may correspond to concepts that cannot be adequately described by a single measure (HAIR JR. et al., 2009).

To identify if the three variables presented above (policy, office, and budget) can be combined into a single factor representing the underlying concept of portfolio importance, we use principal component analysis as an extraction method. This method is especially appropriate because it summarizes most of the original variance in a minimum number of factors (HAIR JR. et al., 2009). In our case, we use principal component analysis to identify if our three variables can be grouped into a single factor. For this reason no rotation technique is necessary. We use eigenvalues greater than 01 as cutoff to determine which factors to extract. Eigenvalues represent the amount of variance accounted for by a factor (HAIR JR. et al., 2009). Because this criterion is more reliable when the number of variables is greater than 20 , we also use the percentage of total variance explained as criteria to determine the number of relevant factors in the analysis. Values greater than 60 percent are usually considered satisfactory (HAIR JR. et al., 2009).

Reliability and validity are fundamental concerns when creating a new way to measure an unobserved concept. Reliability is the degree of consistency between multiple measurements of a variable. We test the reliability of our new measure with an analysis of its internal consistency. "The rationale for internal consistency is that the individual items or indicators of the scale should all be measuring the same construct and thus be highly correlated" (HAIR JR. et al., 2009, p. 125). We use Chronbach's Alpha as a measure of consistency of this new composite measure. Values greater than 0.60 are considered satisfactory.

Validity is the extent to which a measure accurately represents the concept of interest. The most common strategy to measure validity is through the correlation with another measure of the same concept, with high correlations indicating that both measures are actually measuring the same thing. However, because to the best of our knowledge there is no other measure of portfolio importance available, this kind of test is not possible. The next section presents the results. 


\section{Results}

Table 01 presents descriptive statistics for all variables considered in the analysis. We present first all variables related to the 'policy' dimension, then 'office', and lastly 'budget'. All 'budget' and 'policy' variables have information available for the 1995-2014 period. For the 'office' variables, data is only available from 1999. Budget variables were deflated to 2014 values and represent the total amount in the annual budgetary law.

Table 01. Descriptive statistics

\begin{tabular}{|c|c|c|c|c|c|}
\hline Variable & $\mathrm{N}$ & Min & Max & Mean & SD \\
\hline Provisional Measure & 428 & 0 & 34 & 3.5 & 5,697 \\
\hline $\begin{array}{l}\text { Constitutional } \\
\text { Amendment }\end{array}$ & 428 & 0 & 14 & 0.32 & 1,480 \\
\hline Ordinary Law & 428 & 0 & 43 & 3.25 & 4,890 \\
\hline Complementary Law & 428 & 0 & 07 & 0.20 & 0,630 \\
\hline Total Legislative Acts & 428 & 0 & 58 & 7.26 & 10,067 \\
\hline Appointees Level 01 & 360 & 0 & 1,246 & 288,54 & 284,974 \\
\hline Appointees Level 02 & 360 & 38 & 1,018 & 226,16 & 187,889 \\
\hline Appointees Level 03 & 360 & 08 & 411 & 139.42 & 92,982 \\
\hline Appointees Level 04 & 360 & 27 & 255 & 104.61 & 49,329 \\
\hline Appointees Level 05 & 360 & 05 & 72 & 31.19 & 14,448 \\
\hline Appointees Level 06 & 360 & 01 & 25 & 6.54 & 3,521 \\
\hline Total Appointees & 360 & 107 & 2,684 & 796.45 & 565,786 \\
\hline Total Budget* & 424 & 357,466 & $454,432,118$ & $31,142,209$ & $61,763,089$ \\
\hline Investment Budget* & 424 & 18,025 & $19,956,882$ & $2,136,579$ & $3,376,384$ \\
\hline
\end{tabular}

Sources: Casa Civil da Presidência da República, Câmara dos Deputados, Secretaria do Tesouro Nacional, and Ministério do Planejamento.

Note: $\left(^{*}\right)$ In $\mathrm{R} \$$ thousands.

Concerning the 'policy' variables, the minimum value is 0 and the maximum is 34 provisional measures, 14 constitutional amendments, 43 ordinary laws, and 07 complementary laws. The mean number of total legislative acts presented by a ministry to the legislature is 7.26 acts. The minimum value is 0 , meaning that a ministry did not introduce a single normative act to the legislature during an entire year. This situation happened 48 times, mostly in the Ministry of Sports and the 
Ministry of Culture. The maximum value is 58, meaning that a ministry participated in the formulation of 58 different acts during a year. This was the Ministry of Planning in 2008. Concerning the 'office' variables, we present descriptive statistics for all political appointees (DAS) levels. We can notice that the greater the DAS rank, the smaller the mean number by ministry. Also, there is great variation between ministries considering the standard-deviations for all levels.

Concerning the 'budget' dimension, the mean budget available to ministries in the federal government is $\mathrm{R} \$ 31$ billion. However, this amount varies greatly between different ministries. The Ministry of Fishery in 2012 had the smallest total budget with $\mathrm{R} \$ 357$ million, and the Ministry of Social Security in 1995 has the greatest total budget with $\mathrm{R} \$ 454$ billion. One common argument about budget allocation in Brazil is that most expenditures are required by law, reducing discretionary power. However, one portion of the budget is actually 'flexible'-the investments budget-and it may be the part that political parties value the most. For this reason we present descriptive statistics for the investments budget. The mean investments budget is $\mathrm{R} \$ 2$ billion. The Ministry of Foreign Affairs in 1999 had the smallest investments budget with $\mathrm{R} \$ 18$ million, and the Ministry of Transport in 2011 had the greatest investments budget with $\mathrm{R} \$ 19$ billion. This comparison shows that, concerning budget, ministries vary greatly in asset availability. Also, a ministry of low visibility such as Transport may be highly valued in one specific dimension such as investments budget.

Which portfolios are the most important to the executive's legislative agenda? Figure 01 presents the portfolio ranking considering the policy dimension. Black dots are means for the period, and vertical bars for standard deviations. To facilitate comparability, all values were standardized to vary from 0 to 01 .

Figure 01 shows that in the 1995-2014 period the most important portfolio, considering policy decision-making, was the Ministry of Finance, followed by Planning, Justice, and State Reform (during its brief existence). This result makes perfect sense considering that these are the 'coordination' ministries. They participate in the formulation of most of the executive's legislative agenda. If a coalition partner seeks influence over policy decisions, these are the most important ministries in the portfolio allocation game. The least important ones, meaning the ministries that have reduced participation in policy formulation 
decisions, are Fishery, Tourism, Culture, and Sports. Of course, one can point out that the formulation of bills is a limited indicator of policy influence considering that a ministry can formulate policy decisions through other instruments, such as decrees. However, the most important and innovative policy decisions usually come from legislative acts submitted to congress, such as the acts considered in the policy dimension indicator.

Figure 01. Ministries compared - policy dimension (means and standard deviations)

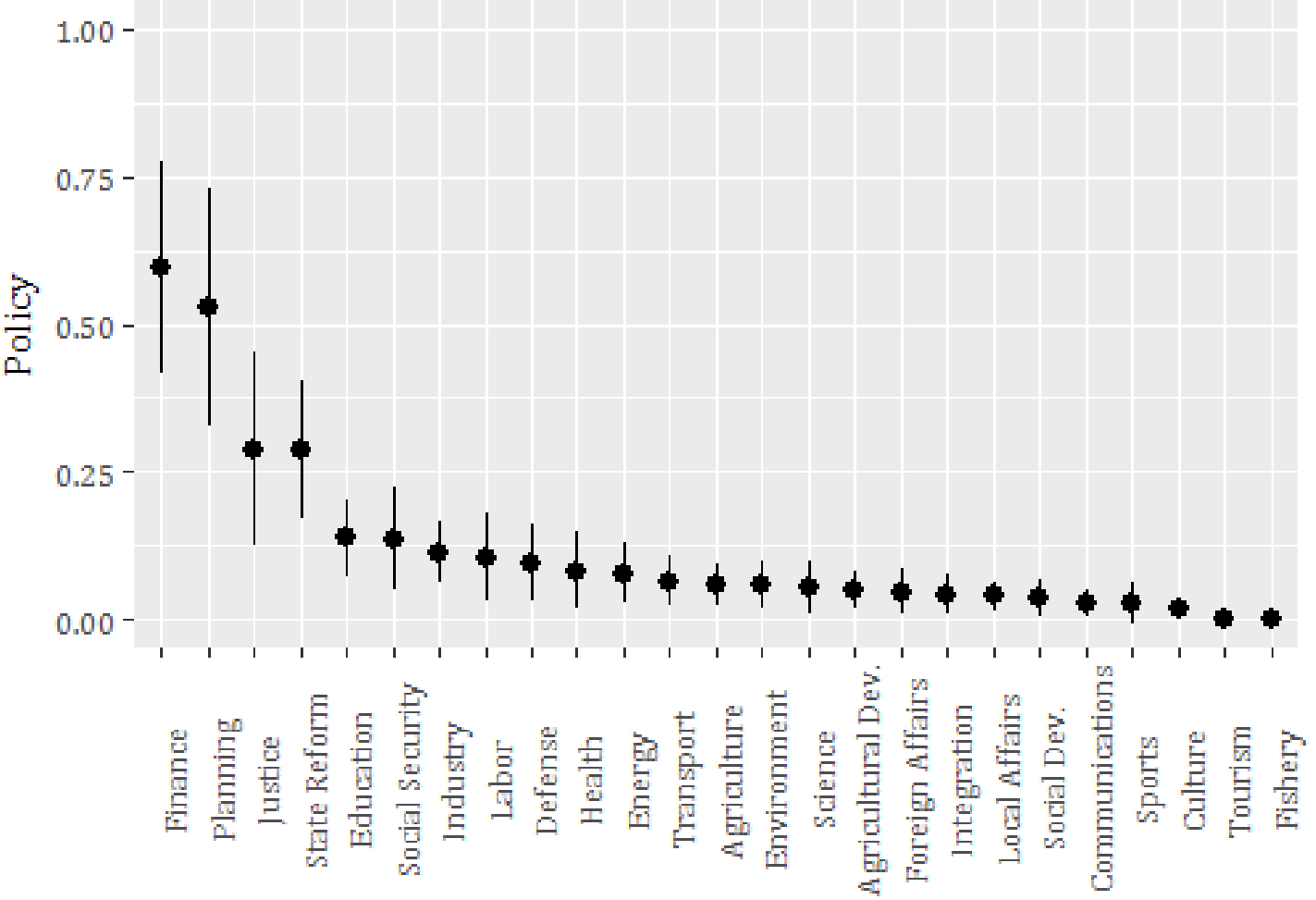

Sources: Casa Civil da Presidência da República and Câmara dos Deputados.

Figure 02 presents portfolios' rankings considering the office dimension. Considering all six DASs levels, the most important ministries are Finance, Health, Justice, Planning, and Social Security. The least important ones in the number of political nominations are Sports, Local Affairs, Tourism, and Communications. One can notice that the distribution is not so different from the policy dimension distribution. This happens because to make policy decisions, trusted personnel are often necessary. This again shows that office allocation may not be all about patronage as common sense may suggest. 
Figure 02. Ministries compared - office dimension (means and standard deviations)

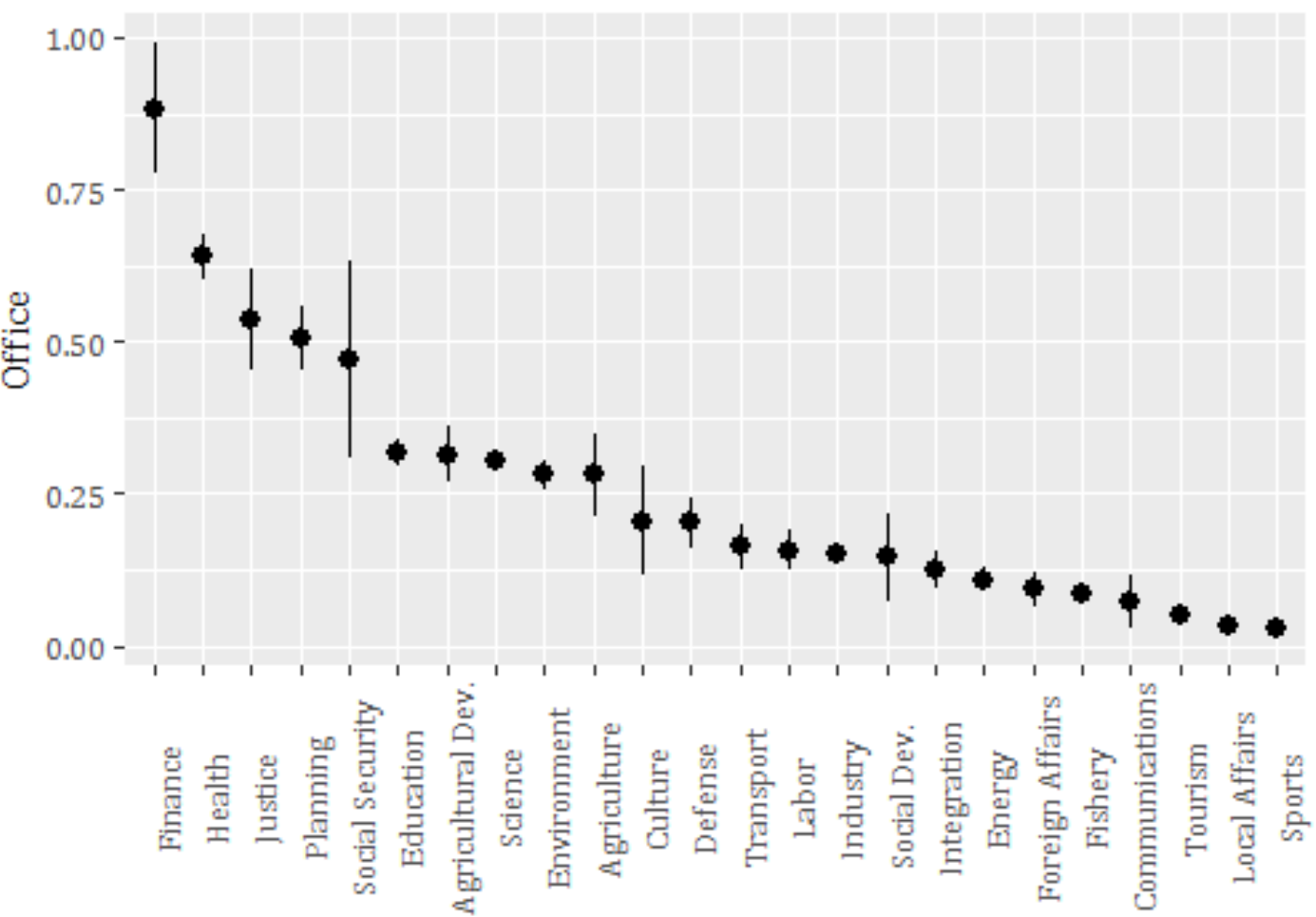

Source: Ministério do Planejamento.

Figure 03 presents portfolios' rankings in the budget dimension. One important characteristic to differentiate ministries in the general debate is the classification as 'big spending' ministries. Figure 03 presents two panels: the one above shows total budget and the one below shows investments budget. This in an important difference considering the most important ministry in the total budget panel, which is Social Security. Social Security is the 'biggest spending' ministry. However, this budget is highly rigid in the sense that the party controlling this ministry cannot do much to use these resources politically to gain votes. Also, the budget allocation decisions that do happen in this ministry are usually negative ones, related to reducing benefits. Health, Defense, and Labor follow Social Security. The least spending ministries are Fishery, State Reform, Culture, and Sports. 
Figure 03. Ministries compared - budget dimension (means and standard deviations) $1.00-$
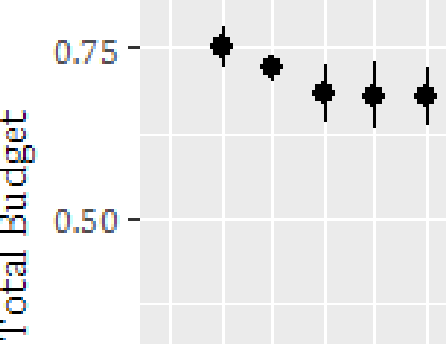

$0.25-$

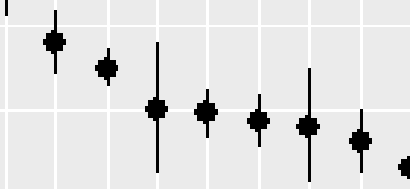

$0.00-$

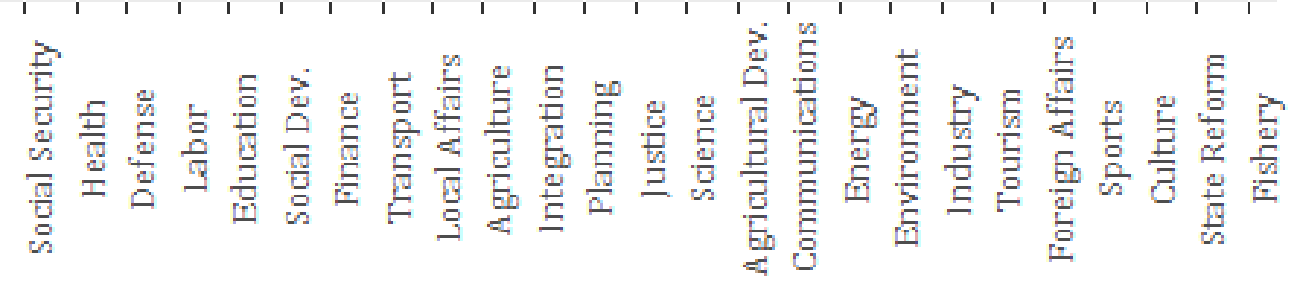

$1.00-$

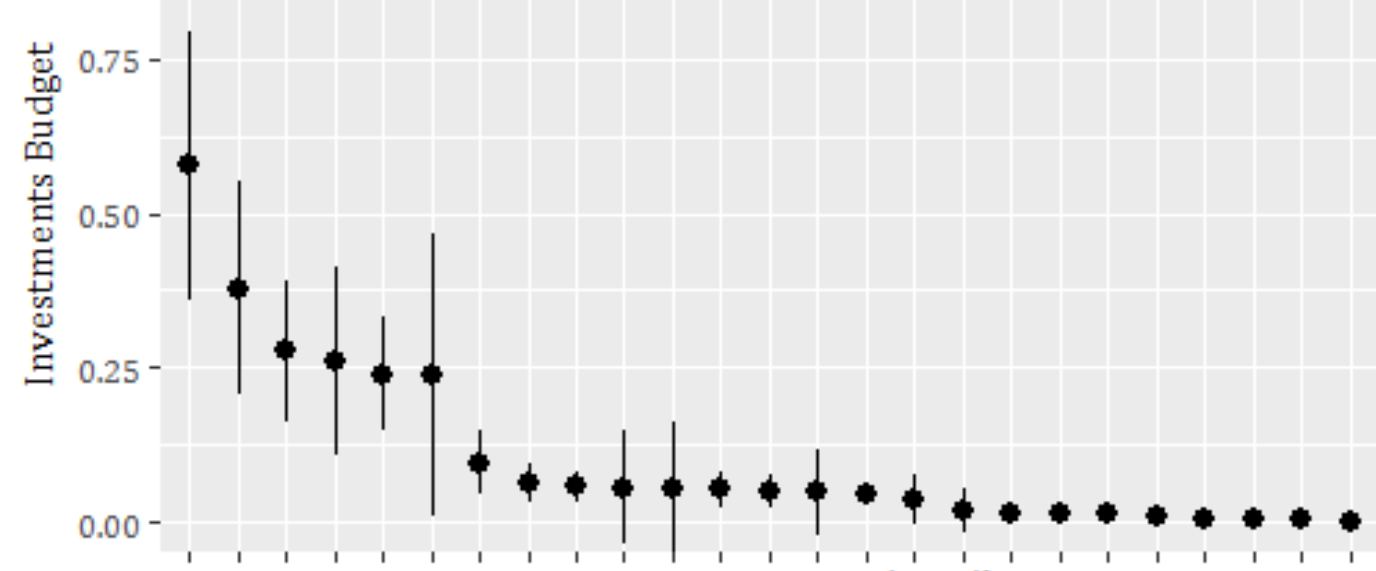

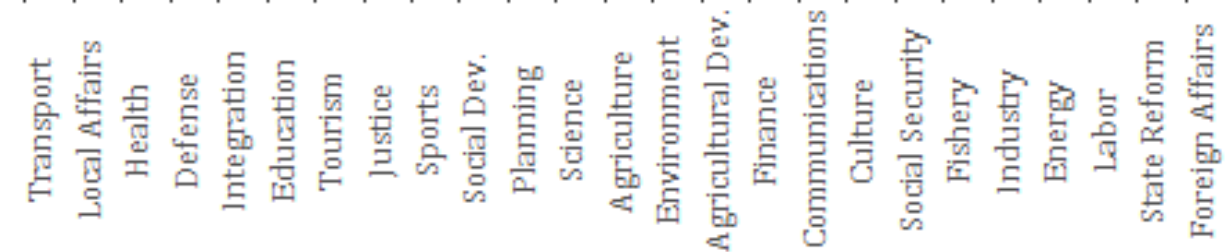

Source: Secretaria do Tesouro Nacional. 
Considering the investments budget, the first thing we notice is that the intervals are much broader, indicating high variance in the sample and that this measure is less reliable. Considering only the 'flexible' part of the budget, the big spending ministries are Transport, Local Affairs, Health, and Defense. This means that to a coalition partner interested in using budget allocation for political gain, these are probably the most important ministries in the portfolio allocation game. The least important ones are Foreign Affairs, State Reform, Labor and Energy.

Comparing all three dimensions, we can notice that some ministries consistently rank higher, and others are continually among the least important. However, some examples stand out, such as Transport, which is ranked average in the policy and office dimensions, but ranks highly in the investments budget. This means that there are important differences between ministries, and depending on what exactly the party seeks in government, a low-visibility ministry can be considered of high importance. Figure 04 presents portfolios' distribution in all three dimensions.

Figure 04. Ministries compared - policy, office, and budget dimensions (means)

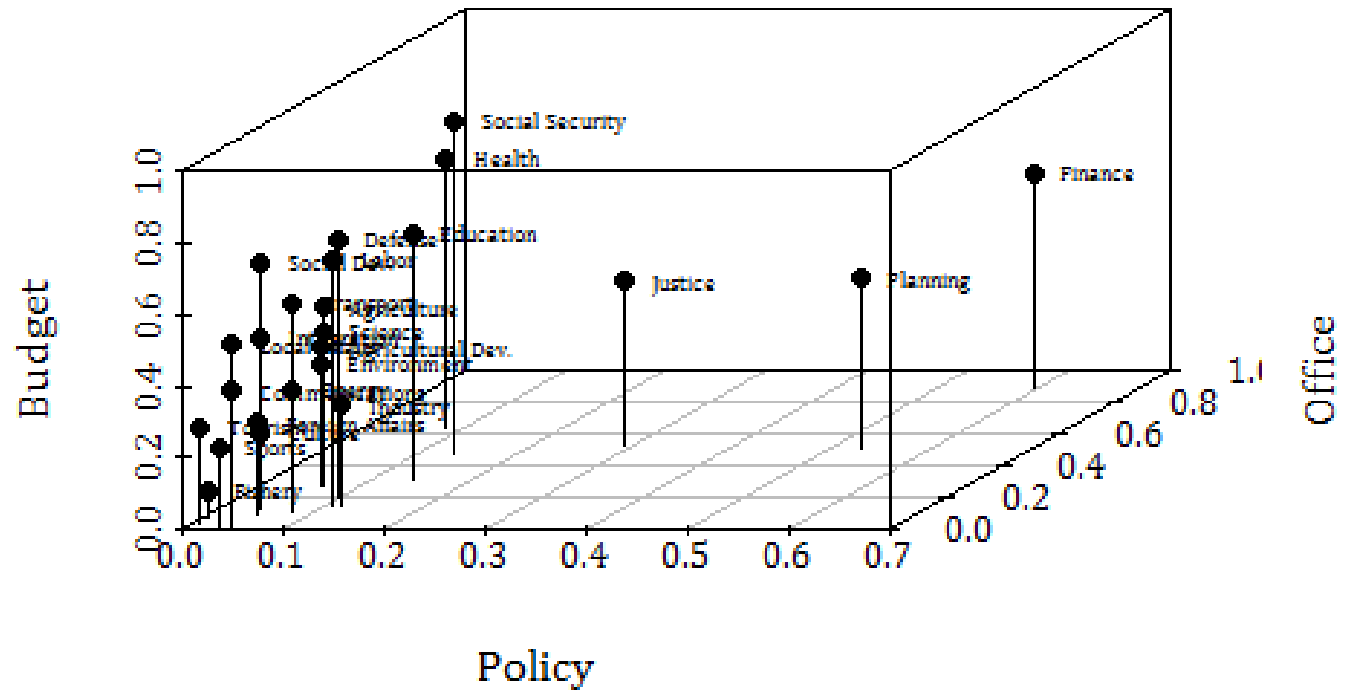

Sources: Casa Civil da Presidência da República, Câmara dos Deputados, Secretaria do Tesouro Nacional, and Ministério do Planejamento. 
The three-dimensional graph above shows the distribution of ministries while simultaneously considering their values in the policy ( $\mathrm{x}$-axis), office (z-axis), and total budget (y-axis) dimensions. All three variables are positively correlated. However, we notice that portfolios of great importance in the policy dimension are also of high importance in the office dimension, with three important extreme cases: Justice, Planning, and Finance. These are high-valued ministries in the policy dimension, standing out from the rest of the distribution as expected since these are considered the government's policy coordinators. Two important outliers in the distribution are Social Security and Health because of the 'big-spending' ministries status. Noticing these differences is important to justify the use of all three dimensions in a composite measure of portfolio importance.

How can these three dimensions combine into a single indicator of portfolio importance? We first present results for the simple index constructed by adding the values of the three variables and considering that all variables have the same weight in the composite index. We first present the ranking of ministries using the total budget for the budget dimension and then present results using the investments budget for this dimension. We present this alternative specification because using the total budget may cause the following problems: First, the total budget includes the budget used to pay the political appointees counted in the office dimension, over-representing this aspect in the final composite measure. Second, the total budget may not be what political parties value in government since most of it is composed of mandatory expenditures. The figures 05 and 06 show the results for both specifications.

The results using our first composite measure of portfolio importance show that the most important ministries are Finance, Planning, Social Security, and Health. The least important ones are Fishery, Sports, Tourism, and Foreign Affairs. Concerning reliability, Chronbach's Alpha for this measure is 0.688, indicating high reliability. However, concerning validity, does this distribution make sense? There are few accounts in the literature about ministerial importance. The mentions are few and not systematic. However, most agree on the importance of the Finance Ministry (AMORIM NETO, 2000; LAVER and SCHOFIELD, 1990), which is indeed the most important ministry in our ranking. However, they also agree that the Ministry of Foreign Affairs is among these most important ministries, and in our ranking, this ministry is ranked 
among the least important ones. Is this a major flaw in the measure? It is possible. But we also consider two other possibilities.

Figure 5. Portfolio importance - simple index with total budget (means and SDs)

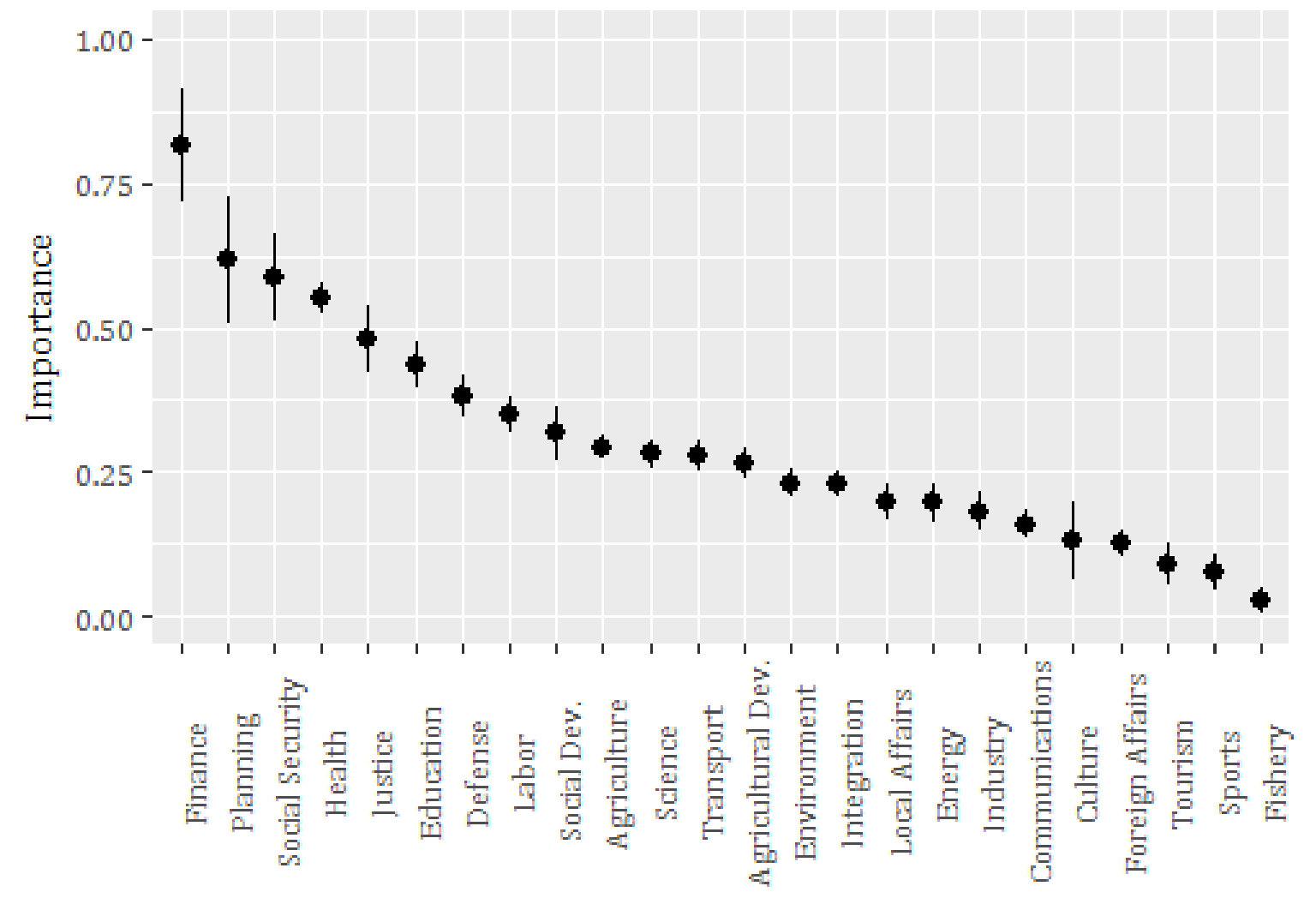

Sources: Casa Civil da Presidência da República, Câmara dos Deputados, Secretaria do Tesouro Nacional, and Ministério do Planejamento.

First, perhaps the importance of the Ministry of Foreign Affairs is greater in countries with strong integration issues such as members of the European Union. It is important to also notice that the salience measures that usually point to the high importance of this ministry are usually calculated using information from these countries. Second, our measure only takes into account the policy, office, and budget dimensions. Aspects such as prestige are not considered for the moment. Figure 06 presents an alternate specification, including the investments budget as proxy for the budget dimension. 
Figure 06. Portfolio importance - simple index with investment budget (means and standard deviations)

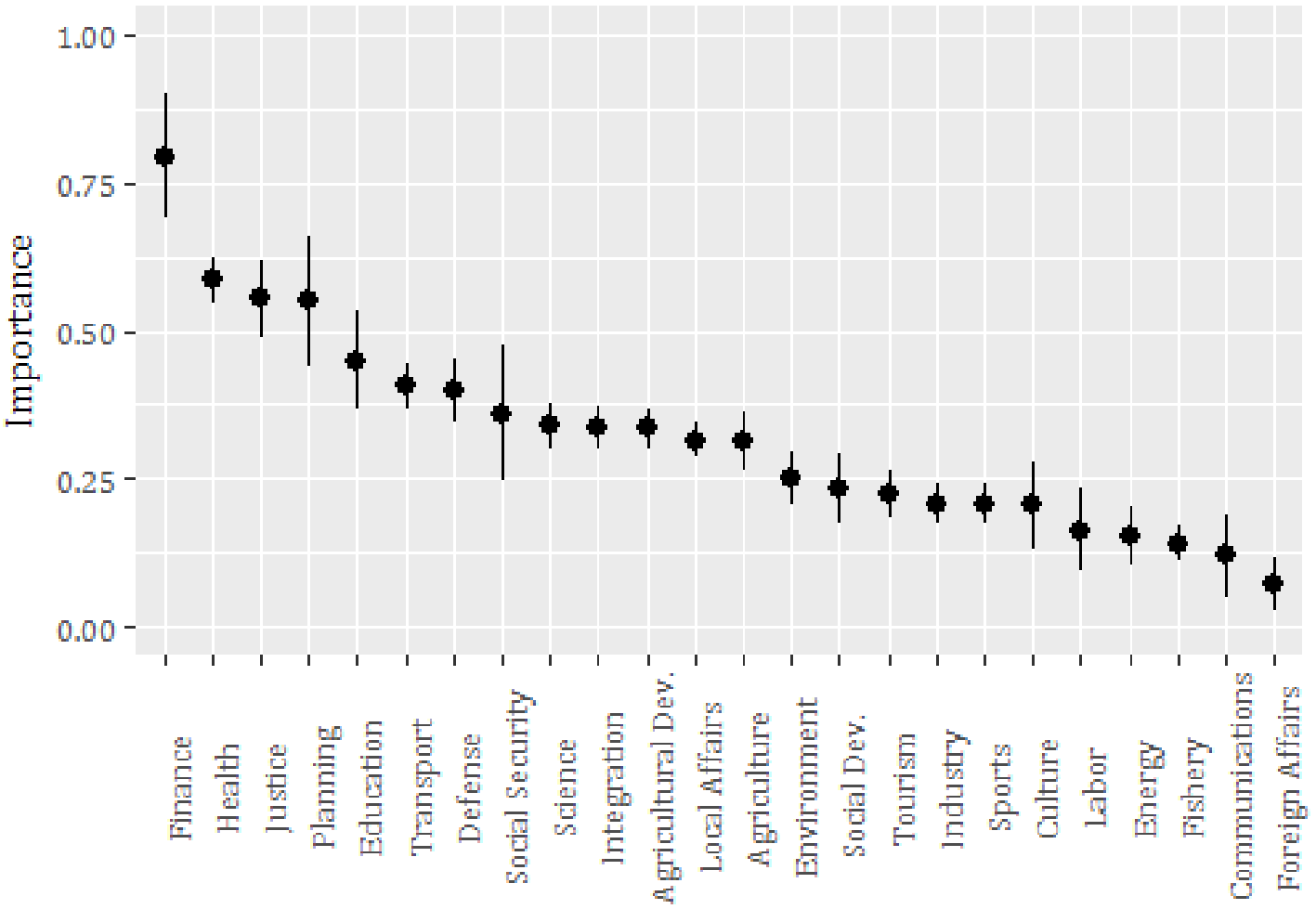

Sources: Casa Civil, Câmara dos Deputados, Secretaria do Tesouro Nacional, and Ministério do Planejamento.

Figure 06 shows that when the investments budget is included in the index, the distribution of ministries changes. Finance continues as the most important ministry, along with Justice and Planning. But now this list includes the Ministries of Health, Education, and Transport. Note that Social Security is no longer the third most important ministry, since its most important asset is the total budget, which is composed almost completely of non-discretionary expenditures. The least important ministry is now Foreign Affairs, followed by Communications, Fishery, and Energy. The theoretical reason for including the investments budget is that political parties may value this asset because of its use as targeted spending and the expected electoral returns of pork barreling. However, as a composite measure this may not be the best strategy since the value of its Chronbach's Alpha is 0.342, indicating low reliability. Perhaps, if the researcher's interest is in the use of targeted spending by cabinet ministers, investments budget should be used on its own and not as part of a composite measure. 
Our final approach to this task of presenting a composite measure of portfolio importance is to use factor analysis and consider the variance in the data to construct the index. This minimizes the subjective judgment about what goes with what and the relative weight of each variable. Because our goal is to propose a single measure, we use all total variables: total legislative acts, total appointees, and total budget 7,8 . The total budget variable is in log scale and all variables were standardized before inclusion in the factor analysis. Tables 02,03 , and 04 present the factor analysis results.

The first step to perform a factor analysis is guaranteeing that this method is appropriate considering the technic assumptions. Our KMO (Kaiser-Meyer-Oklin) test was 0.514 , indicating that the matrix can be factored. Also, our Bartlett's test of sphericity was significant at $<0.01$, indicating the existence of sufficient correlations between variables.

Table 02. Communalities

\begin{tabular}{ccc}
\hline Variable & Initial & Extraction \\
\hline Legislative Acts & 1.000 & 0.649 \\
Total Budget & 1.000 & 0.394 \\
Appointees & 1.000 & 0.829
\end{tabular}

Sources: Casa Civil da Presidência da República, Câmara dos Deputados, Secretaria do Tesouro Nacional, and Ministério do Planejamento.

Table 03. Total variance explained

\begin{tabular}{ccccccc}
\hline \multirow{2}{*}{ Component } & \multicolumn{3}{c}{ Initial Eigenvalues } & \multicolumn{3}{c}{ Extraction Sums of Squared Loadings } \\
& Total & $\begin{array}{c}\% \\
\text { Variance }\end{array}$ & $\begin{array}{c}\text { Cumulative } \\
\%\end{array}$ & Total & $\begin{array}{c}\% \\
\text { Variance }\end{array}$ & $\begin{array}{c}\text { Cumulative } \\
\%\end{array}$ \\
\hline 1 & 1,871 & 62.36 & 62.36 & 1,871 & 62.36 & 62.36 \\
2 & 0.830 & 27.67 & 90,040 & & & \\
3 & 0.299 & 9.96 & 100.00 & & & \\
\hline
\end{tabular}

Sources: Casa Civil da Presidência da República, Câmara dos Deputados, Secretaria do Tesouro Nacional, and Ministério do Planejamento.

\footnotetext{
${ }^{7}$ Using all variables presented in table 01 would just create three factors grouping the office, policy, and budget variables. The results for this factor analysis can be supplied upon request.

${ }^{8}$ As seen above, investments budget reduces the reliability of the measure and also does not achieve appropriate values in any of the factor analysis tests. For this reason we do not present these results.
} 
Table 04. Component matrix

\begin{tabular}{cc}
\hline Variable & Component \\
\hline Legislative Initiatives & 0.80 \\
Total Budget & 0.62 \\
Appointees & 0.91 \\
\hline
\end{tabular}

Sources: Casa Civil da Presidência da República, Câmara dos Deputados, Secretaria do Tesouro Nacional, and Ministério do Planejamento.

Table 02 shows communalities. These indicate the amount of variance in each variable that is actually extracted, or the variance that is accounted for by the factor solution. The literature indicates that only variables with extraction $>0.5$ should be included in the final solution. However, due to theoretical importance of the total budget variable and the proximity to the threshold value, we decided to keep it in the final solution. Table 03 shows that only the first factor achieves both criteria for extraction: eigenvalues $>01$ and total variance explained $>60$ percent. This means that only the first factor should be extracted and that this first factor represents the best linear combination of our three variables. This also means that the policy, office, and budget indicators can be combined into a single composite measure, representing portfolio importance. Finally, table 04 presents loadings in the component matrix. Loadings are correlations between the factor and each variable. Loadings $>0.30$ are considered the minimal requirement. All three variables exceed this minimum requirement, showing high correlations with the factor, indicating that the factor extracted represents well the original variables. Also, all three variables show positive correlations with the factor, indicating that they all vary in the same direction.

The factor analysis' results were all satisfactory considering our goal to reduce policy, office, and budget into a single composite measure. As to the reliability of this new measure, Cronbach's Alpha is also 0.688 (same variables as the first index), a value greater than the minimum required, indicating the composite measure's reliability. Figure 07 shows the final ranking of ministries based on their respective importance. The values were standardized to vary from 0 to 01 . 
Figure 07. Portfolio importance - factor analysis with total budget (means and standard deviations)

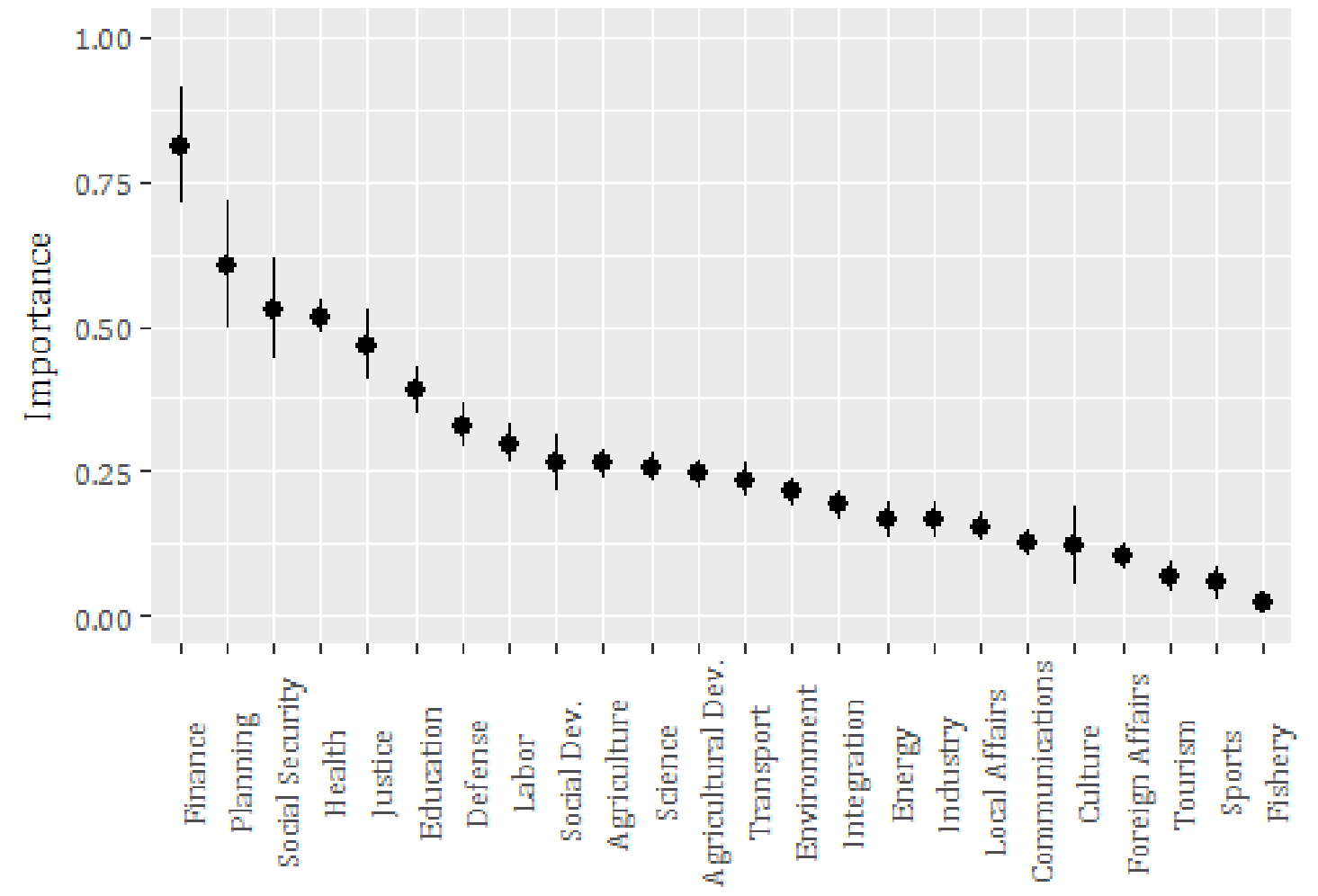

Sources: Casa Civil da Presidência da República, Câmara dos Deputados, Secretaria do Tesouro Nacional, and Ministério do Planejamento.

The results show that the Finance, Planning, and Social Security Ministries are the most important, and the Fishery, Sports, and Tourism Ministries are the least important. Because there is no other measure of importance available, the validity of the measure proposed here remains open for discussion. However, as seen above, this distribution does make sense considering the limited discussion of this topic in this literature.

One other aspect to emphasize is that all three indexes presented here are highly correlated. Table 05 shows the correlation matrix for our three composite measures. All three specifications of the importance composite measure are highly correlated, and therefore are measuring the same concept. However, the measure constructed using factor analysis shows the higher correlations with the two simple indexes, and for this reason we argue that this is the best final solution. 
Table 05. Correlation matrix - factor analysis and simple indexes

\begin{tabular}{lccc}
\hline & $\begin{array}{c}\text { Simple Index 01 } \\
\text { (total budget) }\end{array}$ & $\begin{array}{c}\text { Simple Index 02 } \\
\text { (investments budget) }\end{array}$ & Factor Analysis Index \\
\hline $\begin{array}{l}\text { Simple Index 01 } \\
\text { (total budget) }\end{array}$ & 01 & $0.864^{* * *}$ & $0.997^{* * *}$ \\
$\begin{array}{l}\text { Simple Index 02 } \\
\text { (investments budget) }\end{array}$ & $0.864^{* * *}$ & 01 & $0.877^{* * *}$ \\
Factor Analysis Index & $0.997^{* * *}$ & & 01 \\
\hline
\end{tabular}

*** P-value $<0.001$

Sources: Casa Civil da Presidência da República, Câmara dos Deputados, Secretaria do Tesouro Nacional, and Ministério do Planejamento.

Presenting this new measure, one immediate matter of concern is that our variables may be considered 'ex-post', meaning that the amount of policy, office, and budget is allocated to ministries after portfolio allocation. We argue that this is not a major limitation, as these variations can be considered marginal since no drastic change in policy initiation, office, and budget allocation is expected. However, to address this subject directly, we compare portfolios across different governments to see if their importance changes. We use the estimates from the factor analysis presented above.

Figure 08. Portfolio importance - governments compared (1999-2014)

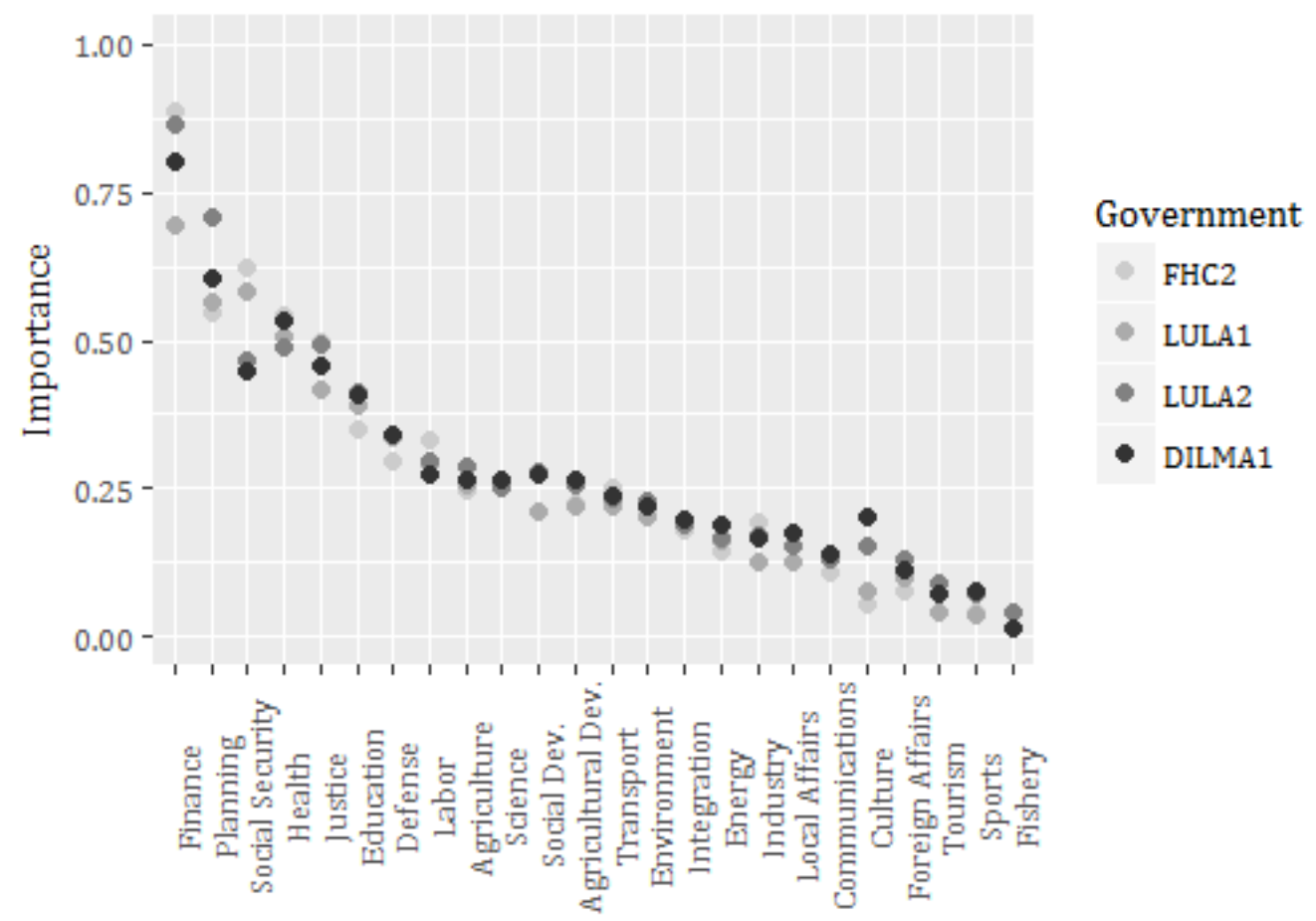

Sources: Casa Civil da Presidência da República, Câmara dos Deputados, Secretaria do Tesouro Nacional, and Ministério do Planejamento. 
From 1999 to 2014, Brazil was governed by Fernando Henrique Cardoso (FHC), Luiz Inácio Lula da Silva (Lula), and Dilma Rousseff (Dilma). All three presidents were elected for two terms. However, we only have data for FHC's second term, both of Lula's terms, and Dilma's first term. All four governments are plotted above to ease comparison. We notice that portfolio importance does not vary much by government, with a few exceptions. These are the Finance, Planning, Social Security, and Culture Ministries. The Ministry of Finance had its greater importance during FHC's second term and its lowest point in Lula's first term. Comparing to the evolution of the Ministry of Planning we can see that these two ministries alternate in the position of most important. Social Security had its importance reduced in Lula's second term, reaching its lowest point in Dilma's first mandate. This is possibly due to the creation of the Social Development Ministry. Lastly, the Ministry of Culture has consistently increased its importance, reaching its highest point during Dilma's government. Despite these exceptions, that are not drastic, the other points almost exactly overlap, indicating constant importance in time.

The main goal of this research note was to present this new measure and to test its reliability the best we could. However, some limitations are clear. First, the validity of the measure is still an open question. As long as other measures of portfolio importance or salience are not developed it is not possible to assert to what extent it is actually measuring what it is supposed to measure. One possible solution in the long term is the conduction of expert surveys and surveys with politicians to understand the perceived importance of portfolios and compare it to the results presented here.

A second limitation is that several other variables could be incorporated in the composite measure, such as number of decrees, or control over state-owned enterprises, or number of programs implemented, or number of regulations, and so forth. However, we decided to keep it simple to increase comparability of different ministries and over time. Another limitation is that this measure does not address the problem that different portfolios may appeal to different parties. For this particular goal, a measure of issue salience would be more appropriate and should be developed in the future. Lastly, this measure also does not answer the question of who gets what in coalition governments in the sense of what exactly coalition partners are able to extract from government participation. We merely present what assets portfolios offer. The political use of these 


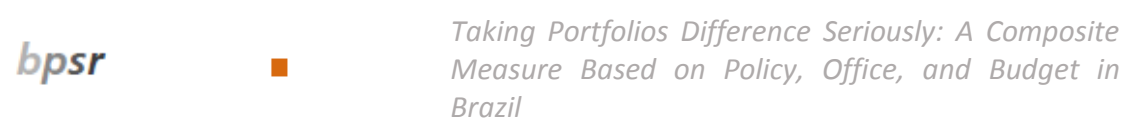

assets is subject to the bargaining between coalition partners and the president and is an ongoing process.

Some possible uses of the measure presented here are the identification of what is the government share each coalition partner controls in government, the president's strategies when allocating portfolio to coalition partners, and also the effects of this precise distribution over executive-legislative relations, party discipline, and coalition stability. We consider this measure as a first step, not the final one. Our hope is that it would open the debate for the development of new measures and discussions about portfolio allocation and coalition governance in Brazil.

\section{Conclusion}

The main objective of this research note was to propose a new measure of portfolio importance in Brazil. Because there is no consensus in specialized literature on a single indicator capable of summarizing the important differences between ministries, our strategy was to minimize bias by including three different dimensions in the analysis: policy, office, and budget. We compare Brazilian ministries in these three different dimensions, showing how high importance in one dimension does not necessarily mean high importance in others. These dimensions alone may not fully summarize a complex concept such as portfolio importance. However, they show that ministries may be valued for different reasons and also may appeal to different political actors.

Using simple indexes and factor analysis, our results indicate that these three variables can be successfully grouped into a single composite indicator of portfolio importance. We identify the Ministry of Finance as the most important ministry and the Ministry of Fishery as the least important one. More than offering results, the goal here was to offer elements to the development of new measures, new approaches, and new questions to the debate about coalition formation and coalition governance in Brazil.

Revised by Lindsey Silva Submitted on February 14, 2016 Accepted on September 29, 2016

\section{References}

AMORIM NETO, Octávio (2000), Gabinetes presidenciais, ciclos eleitorais e disciplina legislativa no Brasil. Dados. Vol. 43, № 03, pp. 479-519. 
AMORIM NETO, Octávio (2006), Presidencialismo e governabilidade nas Américas. Rio de Janeiro: Editora FGV. 216 pp..

AXELROD, Robert (1970), Conflict of interest: a theory of divergent goals with applications to politics. Chicago: Markham. 216 pp..

BATISTA, Mariana (2013), O Poder no executivo: uma análise do papel dos ministérios e da presidência no presidencialismo de coalizão brasileiro (1995-2010). Opinião Pública. Vol. 19, № 02, pp. 449-473.

BUDGE, Ian and LAVER, Michael (1986), Office seeking and policy pursuit in coalition theory. Legislative Studies Quarterly. Vol. 11, № 04, pp. 485-506.

CHEIBUB, José Antônio; PRZEWORSKI, Adam, and SAIEGH, Sebastian (2004), Government coalitions and legislative success under presidentialism and parliamentarism. British Journal of Political Science. Vol. 34, № 04, pp. 565-587.

FIGUEIREDO, Argelina and LIMONGI, Fernando (2001), Executivo e legislativo na nova ordem constitucional. Rio de Janeiro: Editora FGV. 232 pp..

GAMSON, William (1961), A theory of coalition formation. American Sociological Review. Vol. 26, № 03, pp. 373-382.

HAIR Jr. , Joseph F.; BLACK, William C.; BABIN, Barry J., and ANDERSON, Rolph E., (2009), Multivariate data analysis. New Jersey: Prentice Hall. 816 pp..

LAVER, Michael (2001), Position and salience in the policies of political actors. In: Estimating the policy position of political actors. Edited by LAVER, Michael. London: Routledge. pp. 66-75.

LAVER, Michael (1998), Models of government formation. Annual Review of Political Science. Vol. 01, № 01, pp. 01-25.

LAVER, Michael and SHEPSLE, Kenneth (1990), Coalitions and cabinet government. The American Political Science Review. Vol. 84, № 03, pp. 873-890.

LAVER, Michael and SHEPSLE, Kenneth (1996), Making and breaking governments: government formation in parliamentary democracies. New York: Cambridge University Press. 298 pp..

LAVER, Michael and HUNT, Ben (1992), Policy and party competition. New York: Routledge. 256 pp..

LAVER, Michael and SCHOFIELD, Norman (1990), Multiparty government: the politics of coalition in Europe. Oxford: Oxford University Press. 308 pp..

MAINWARING, Scott (2001), Sistemas partidários em novas democracias: o caso do Brasil. Rio de Janeiro: Editorial Mercado Aberto/Fundação Getúlio Vargas. 420pp. 
MAINWARING, Scott (1993). Democracia Presidencialista multipartidária: o caso do Brasil. Lua Nova. № 28-29, pp. 21-74.

NICOLAU, Jairo (2006), 0 sistema eleitoral de lista aberta no Brasil. Dados. Vol. 49, № 04, pp. 689-720.

PEREIRA, Carlos and MUELLER, Bernardo (2003), Partidos fracos na arena eleitoral e partidos fortes na arena legislativa: a conexão eleitoral no Brasil. Dados. Vol. 46, № 04, pp. 735-771.

PRAÇA, Sérgio; FREITAS, Andrea, and HOEPERS, Bruno (2011), Political appointments and coalition management in Brazil, 2007-2010. Journal of Politics in Latin America. Vol. 03, № 02, pp. 141-172.

SWAAN, Abram de (1973), Coalition theories and cabinet formation: a study of formal theories of coalition formation applied to nine European parliaments after 1918. Amsterdam: Elsevier. 347 pp..

WARWICK, Paul V. and DRUCKMAN, James N. (2001), Portfolio salience and proportionality of payoffs in coalition governments. British Journal of Political Science. Vol. 31, № 04, pp. 627-649. 